\title{
Directional Solidification and Convection in Small Diameter
}

\section{Crucibles}

Jun Chen

Cleveland State University

Follow this and additional works at: https://engagedscholarship.csuohio.edu/encbe_facpub

Z'r. Sung

Univertity of Arizonamical Engineering Commons

How does access to this work benefit you? Let us know!

\$ubfisirier's Statement Univeristy of Arizona

NOTICE. this is the author's version of a work that was accepted for publication in Materials

Blciende EmolhEhlgineering A-Structural Materials Properties Microstructure and Processing.

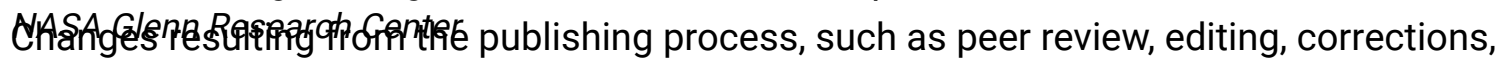
structural formatting, and other quality control mechanisms may not be reflected in this document. Changes may have been made to this work since it was submitted for publication. A definitive version was subsequently published in Materials Science and Engineering A-Structural Materials Properties Microstructure and Processing, 357, 1-2, (September 25, 2003) DOI 10.1016/S0921-5093(03)00223-5

\section{Original Citation}

Chen, J., Sung, P., Tewari, S., Poirier, D., , \& de Groh III, H. (2003). Directional solidification and convection in small diameter crucibles. Materials Science and Engineering: A, 357(1-2), 397 - 405. doi:10.1016/ S0921-5093(03)00223-5

\section{Repository Citation}

Chen, Jun; Sung, P. K.; Poirier, D. R.; and de Groh, H. C. III, "Directional Solidification and Convection in Small Diameter Crucibles" (2003). Chemical \& Biomedical Engineering Faculty Publications. 55.

https://engagedscholarship.csuohio.edu/encbe_facpub/55

This Article is brought to you for free and open access by the Chemical \& Biomedical Engineering Department at EngagedScholarship@CSU. It has been accepted for inclusion in Chemical \& Biomedical Engineering Faculty Publications by an authorized administrator of EngagedScholarship@CSU. For more information, please contact library.es@csuohio.edu. 


\title{
Directional solidification and convection in small diameter crucibles
}

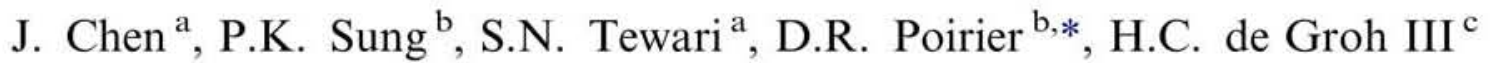 \\ a Chemical Engineering Department, Cleveland State University, Cleveland, OH 44115, USA \\ ${ }^{\mathrm{b}}$ Department of Materials Science and Engineering, The University of Arizona, Tucson, AZ 85721, USA \\ ${ }^{c}$ Advanced Metallics Branch, NASA-Glenn Research Center, Cleveland, OH 44135, USA
}

\section{Introduction}

It is well established that convection influences the planar-to-cellular transition [1-4] and primary cellular/ dendritic spacings [5-7]. During directional solidification (DS) the thermal profile in the melt provides stability against convection because the melt density decreases with increasing temperature. However, the solutal profile in the melt is stabilizing only for those alloys where the increased solute content results in higher melt density (e.g. hypoeutectic $\mathrm{Al}-\mathrm{Cu}$ alloys). Even for these alloys the radial thermal gradient at the triple junction of the solid-liquid interface and the ampoule wall causes mild convection that is localized in the vicinity of the liquid-solid interface $[8,9]$. The solutal profile in the melt is destabilizing for those alloys in which the melt density decreases with increased solute content (e.g. hypoeutectic $\mathrm{Pb}-\mathrm{Sb}$ alloys). It causes extensive convection in the overlying and interdendritic melt and results in macrosegregation along the solidified length for the planar, cellular or dendritic morphologies [10,11].

Since the theoretical dendrite growth and morphology models consider only the diffusive thermal and solutal transports, attempts have been made to eliminate convection in order to allow for a quantitative comparison of the theoretical predictions with the experimental observations $[9,12]$. Effecting DS without convection could also provide data that could be used to deduce diffusion coefficients in alloy melts. In a recent study it has been shown that reducing the ampoule diameter to about $1 \mathrm{~mm}$ almost completely eliminates convection during $\mathrm{DS}$ of $\mathrm{Al}-4$ wt. $\% \mathrm{Cu}$ alloy [8,9]. The purpose of this research was to examine if a similar reduction in the ampoule diameter can reduce the more intense, longer range, convection that occurs during $\mathrm{DS}$ of $\mathrm{Pb}-2.2 \mathrm{wt} . \%$ $\mathrm{Sb}$ alloy. The experiments are supported by simulations of the convection, using a finite element model that has been used for the solidification of alloys [13-15].

\section{Experimental procedures}

Since the DS furnace is described elsewhere [10,11], only a brief description of its operation is provided here. 
The furnace assembly is withdrawn and the sample is held stationary during DS. In addition, the whole assembly sits on top of a vibration isolation platform. Samples are kept in quartz ampoules and are directionally solidified in a flowing argon atmosphere. The furnace is initially translated downwards to remelt the cast alloy feed stock and about $1 \mathrm{~cm}$ of a $5 \mathrm{~cm}$ long seed crystal (length parallel to [100]). The furnace is then translated upwards to achieve the DS. After solidifying for about $10 \mathrm{~cm}$, the rest of the melt column is quenched by withdrawing the furnace rapidly and blasting the ampoule surface with helium gas that is cooled in a tank of liquid nitrogen.

Cast $\mathrm{Pb}-2.2$ wt.\% Sb feedstock-rods were placed into quartz ampoules (7 $\mathrm{mm}$ inner diameter) on top of the single crystal seeds. An ampoule also contained a bundle of 1,2 and $3 \mathrm{~mm}$ inner diameter quartz capillaries that were connected to a vacuum. The furnace was first lowered in order to melt the charge and about $1 \mathrm{~cm}$ portion of the seed. A $20-22 \mathrm{~cm}$ long melt-column was then sucked into the capillaries by inserting the capillary bundle into the melt and activating the vacuum. The capillaries were further lowered till their bottoms were near the liquid-solid interface, and then the entire assembly was directionally solidified at $10 \mu \mathrm{m} \mathrm{s}^{-1}$ for a distance of about $5 \mathrm{~cm}$. This method of casting provided a directionally solidified portion at the bottom of the capillaries that was parallel to [100] and ensured that during subsequent remelting and DS the samples grew along [100].

The pre-cast 1,2 and $3 \mathrm{~mm}$ ID capillary samples were bundled together and kept inside another $7 \mathrm{~mm}$ ID quartz ampoule. The capillary bundle was surrounded by gallium metal kept in the $7 \mathrm{~mm}$ ID ampoule in order to ensure that all of the samples solidified under identical thermal conditions. After remelting about 14 $\mathrm{cm}$ long portion (leaving about $3 \mathrm{~cm}$ long [100] oriented solid at the bottom), the capillary samples were directionally solidified at $0.4 \mu \mathrm{m} \mathrm{s}^{-1}$ at a thermal gradient of $82 \mathrm{~K} \mathrm{~cm}^{-1}$. Two $7 \mathrm{~mm}$ diameter samples were also directionally solidified at $120 \mathrm{~K} \mathrm{~cm}^{-1}$ and a growth speed of $0.4 \mu \mathrm{m} \mathrm{s}^{-1}$ in order to examine the influence of transverse magnetic field $(0.45 \mathrm{~T})$ on convection. One sample was grown in the transverse magnetic field, and the other without the field.

Samples with dendritic morphologies were obtained by DS at 3 and $30 \mu \mathrm{m} \mathrm{s}^{-1}$ with a thermal gradient of 82 $\mathrm{K} \mathrm{cm}^{-1}$. The growth speed of $3 \mu \mathrm{m} \mathrm{s}^{-1}$ corresponds to

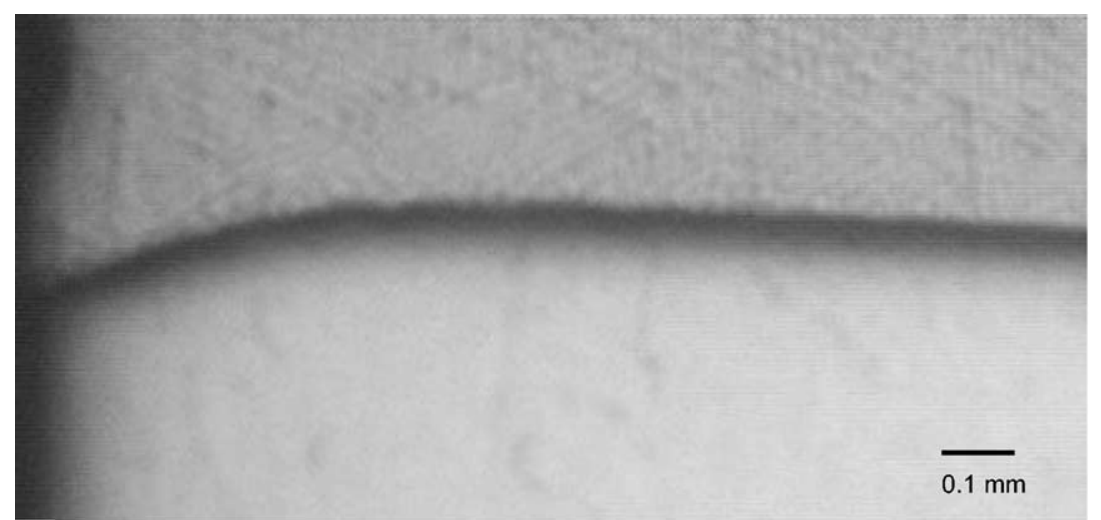

(a)

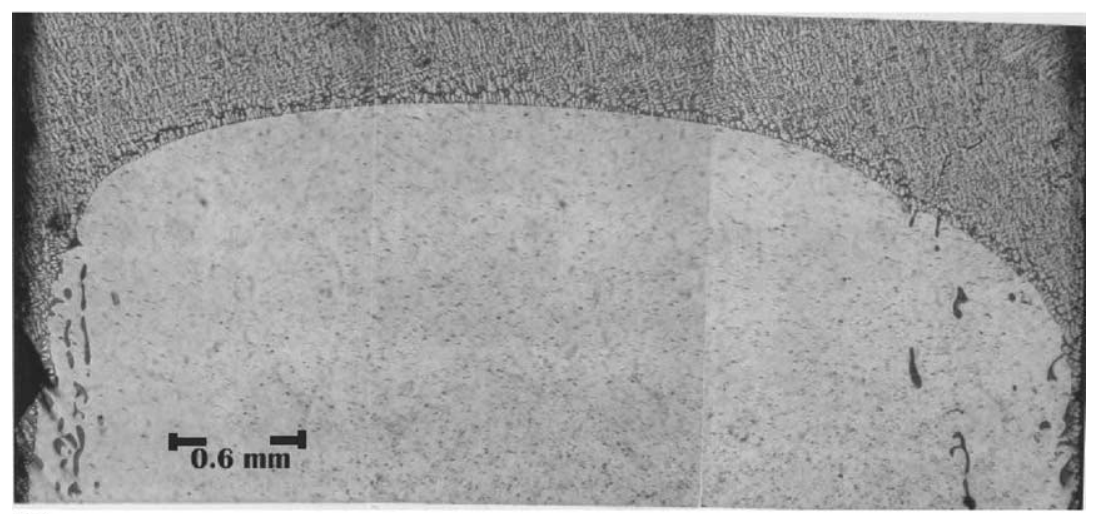

(b)

Fig. 1. Typical morphology of liquid-solid interface during plane front DS of (a) $\mathrm{Pb}-2.2 \mathrm{wt} . \% \mathrm{Sb}$ and (b) Al-2 wt.\% Cu alloy. Notice the convex liquid-solid interface for the $\mathrm{Al}-\mathrm{Cu}$ alloy as compared with nearly flat interface for the $\mathrm{Pb}-\mathrm{Sb}$ alloy. The radial solute segregation has lead to the break-down of the planar front near the periphery of the $\mathrm{Al}-\mathrm{Cu}$ sample, where cellular morphology has evolved. 
the dendrites in the vicinity of the cell-to-dendrite transition, whereas at $30 \mu \mathrm{m} \mathrm{s}^{-1}$ the morphology is within the fully dendritic regime.

The directionally solidified samples were sectioned along their lengths in order to obtain slices, about $2 \mathrm{~mm}$ thick, for chemical analysis by atomic absorption spectroscopy. A specimen about $2 \mathrm{~cm}$ long in the vicinity of the quenched liquid-solid interface was used for optical metallography.

In addition to $\mathrm{DS}$ of the $\mathrm{Pb}-\mathrm{Sb}$ alloy, a $\mathrm{DS}$ experiment on $\mathrm{Al}-2 \mathrm{wt} . \% \mathrm{Cu}$ alloy was also performed. The $\mathrm{Al}-\mathrm{Cu}$ alloy was solidified in an alumina tube with an internal diameter of $6 \mathrm{~mm}$. This alloy was solidified in a thermal gradient of $90 \mathrm{~K} \mathrm{~cm}^{-1}$ at $0.5 \mu \mathrm{m} \mathrm{s}^{-1}$. It was also solidified in a transverse magnetic field $(0.45 \mathrm{~T})$ and with no magnetic field.

\section{Experimental results and discussion}

$\mathrm{DS}$ of $\mathrm{Pb}-2.2 \mathrm{wt} . \% \mathrm{Sb}$ results in thermally stable and solutally unstable density profile in the melt above the planar liquid-solid interface. This results in extensive convection of the liquid as indicated by the experimentally observed longitudinal macrosegregation and computer simulations. For this alloy the planar liquid-solid interface is essentially flat with some curvature next to the quartz ampoule (Fig. 1(a)). On the other hand, the solutal profile and the thermal profile in the melt are expected to be stable against natural convection during DS of Al-2 wt.\% Cu alloy, because copper enrichment results in increased melt density. Ideally one should expect a diffusive solutal profile during plane front growth of $\mathrm{Al}-\mathrm{Cu}$ alloy. However, this alloy grown at 90 $\mathrm{K} \mathrm{cm}^{-1}$ and $0.5 \mu \mathrm{m} \mathrm{s}^{-1}$ also shows evidence of convection as indicated by the convex (towards the liquid) shape of the liquid-solid interface (Fig. 1(b)). The major contributing factor that makes the shape convex is the solutal accumulation near the outer portion of the sample. This is driven by a convection, due to the radial thermal gradients, that is localized in the melt in the immediate vicinity of the liquid-solid interface. This convection, however, produces less severe longitudinal macrosegregation compared with the $\mathrm{Pb}-$ $2.2 \mathrm{wt} . \% \mathrm{Sb}$ alloy as shown below.

\subsection{Influence of transverse magnetic field}

Fig. 2 shows the variation in solute content in the $\mathrm{Pb}-$ 2.2 wt. \% $\mathrm{Sb}$ and $\mathrm{Al}-2 \mathrm{wt} . \% \mathrm{Cu}$ alloy samples grown in 7 $\mathrm{mm}$ ID quartz and $6 \mathrm{~mm}$ ID alumina ampoules, respectively, and with and without the application of magnetic field. It plots $C_{\mathrm{s}} / C_{\mathrm{o}}$, where $C_{\mathrm{s}}$ is the solute content after DS and $C_{\mathrm{o}}$ is the initial solute content. The solutal profiles in this figure are clearly not those expected from diffusive mass-transport. The segregation patterns indicate extensive convection during DS of the $\mathrm{Pb}-\mathrm{Sb}$ alloy and even some convection in the $\mathrm{Al}-\mathrm{Cu}$ alloy. For diffusive transport, one would expect a steady-state value of unity for $C_{\mathrm{s}} / C_{\mathrm{o}}$ after an initial transient, during which the solute content increases from $k C_{\mathrm{o}}$, where $k$ is the equilibrium partition ratio. The length of the transient would be expected to be $D / R k$ [16], where $D$ is the solutal diffusivity in the melt and $R$ is the growth speed. For example, the value of $D / R k$ is $0.9 \mathrm{~cm}$ for the $\mathrm{Pb}-2.2 \mathrm{wt} . \% \mathrm{Sb}$ alloy grown at $0.4 \mu \mathrm{m}$

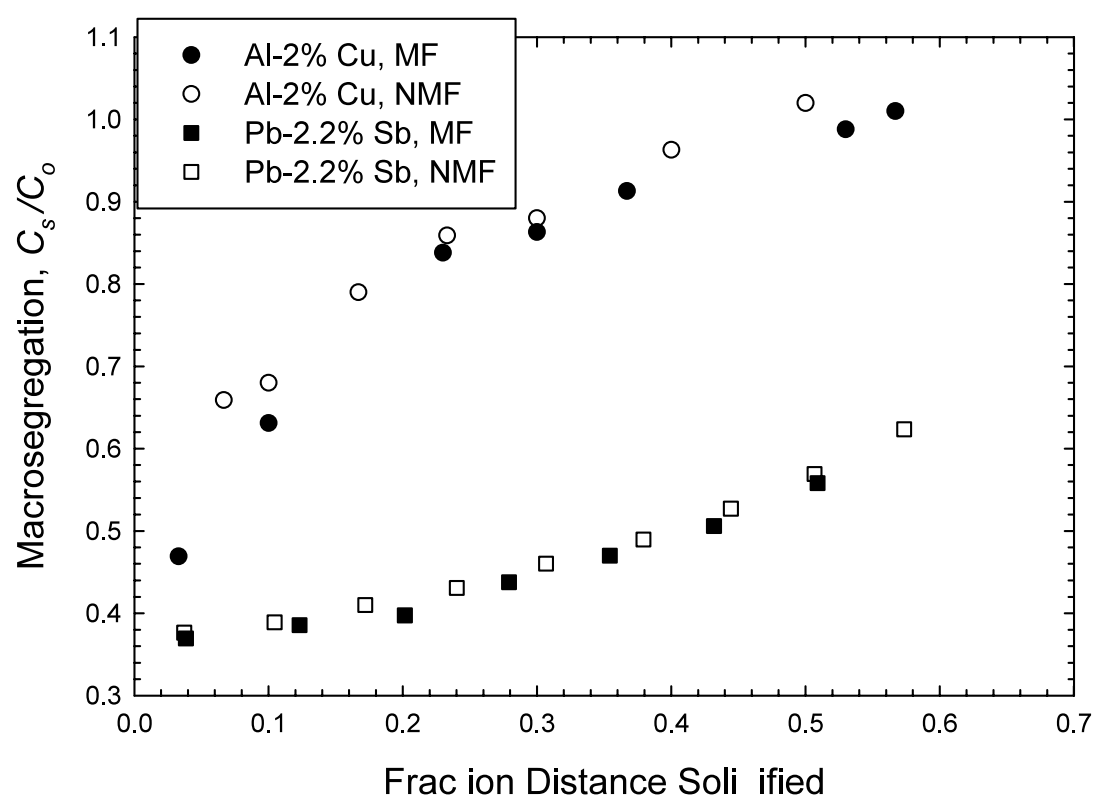

Fig. 2. Macrosegregation along directionally solidified length of $\mathrm{Pb}-2.2 \mathrm{wt} . \% \mathrm{Sb}$ alloy grown in $7 \mathrm{~mm}$ ID quartz crucibles at $0.4 \mu \mathrm{m} \mathrm{s}{ }^{-1}$ and $120 \mathrm{~K}$ $\mathrm{cm}^{-1}$; and of an $\mathrm{Al}-2 \mathrm{wt} . \% \mathrm{Cu}$ alloy grown in $6 \mathrm{~mm} \mathrm{ID} \mathrm{alumina} \mathrm{crucibles} \mathrm{at} 90 \mathrm{~K} \mathrm{~cm}^{-1}$ and $0.5 \mu \mathrm{m} \mathrm{s}^{-1}$. Each alloy was grown in the presence of a transverse magnetic field of $0.4 \mathrm{~T}(\mathrm{MF})$ and without it (NMF). 


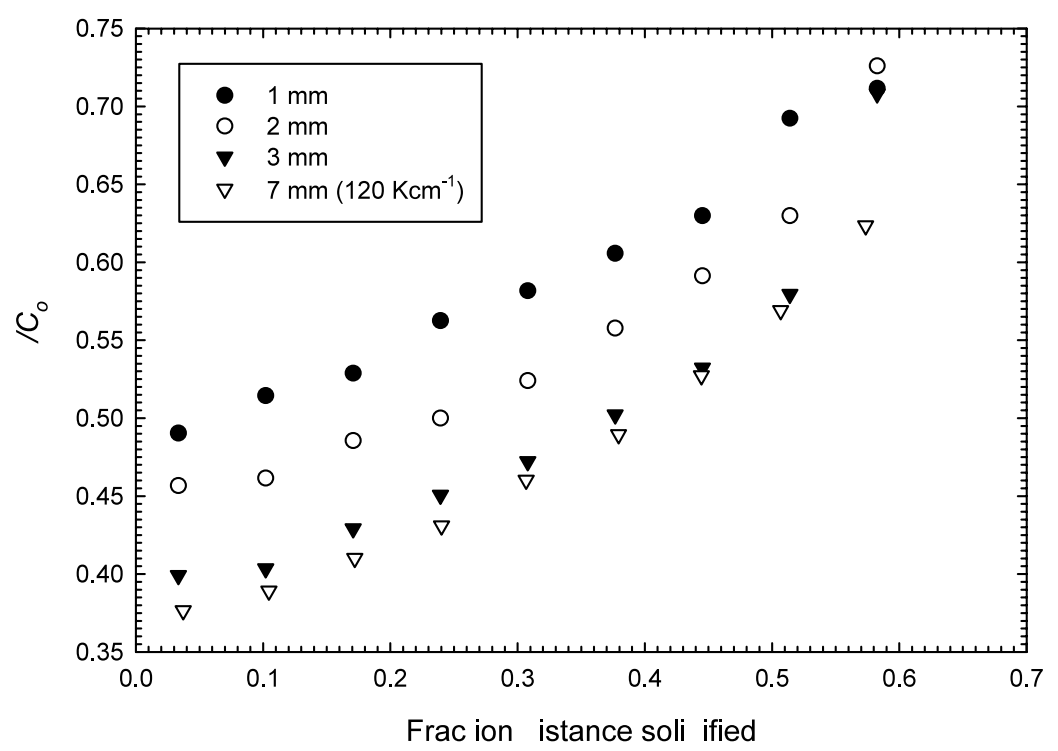

Fig. 3. Influence of reducing the ampoule diameter on the longitudinal macrosegregation in directionally solidified $\mathrm{Pb}-2.2 \mathrm{wt} . \% \mathrm{Sb}$ alloy samples (plane front). The 1,2 and $3 \mathrm{~mm}$ samples were grown at $0.4 \mu \mathrm{m} \mathrm{s}^{-1}, 82 \mathrm{~K} \mathrm{~cm}^{-1}$, while the $7 \mathrm{~mm}$ sample was grown at $0.4 \mu \mathrm{m} \mathrm{s}{ }^{-1}, 120 \mathrm{~K} \mathrm{~cm}^{-1}$.

$\mathrm{s}^{-1}$. The extent of longitudinal macrosegregation in the $\mathrm{Pb}-\mathrm{Sb}$ alloy is significantly higher than that in the $\mathrm{Al}-$ $\mathrm{Cu}$ alloy, and an application of a $0.4 \mathrm{~T}$ transverse magnetic field does not have any influence on the extent of the macrosegregation.

\subsection{Effect of reducing the ampoule diameter}

Fig. 3 compares the dimensionless concentration along the solidified length for the 1, 2, 3 and $7 \mathrm{~mm}$ diameter $\mathrm{Pb}-2.2$ wt.\% $\mathrm{Sb}$ samples that were directionally solidified with a planar liquid-solid interface. The extent of macrosegregation shows a systematic decrease with the decreasing ampoule diameter. This indicates that the intensity of convection decreases with decreasing ampoule diameter, but that even with a diameter as small as $1 \mathrm{~mm}$ convection persists.

\section{Computer simulations}

Details of the solidification/convection model and the computer program are given elsewhere [13-15] and not repeated here. In the momentum and continuity equations, the following assumptions are invoked: the liquid is Newtonian and the flow is laminar; the Boussinesq approximation is made in the buoyancy term of the momentum equation; the solid phase is stationary; and the densities of solid $\left(\rho_{\mathrm{s}}\right)$ and liquid $\left(\rho_{1}\right)$ are different but constant. The mushy zone is treated as a porous medium in which the intergranular/interdendritic liquid convects within a solidifying dendritic solid-network. The model comprises comprehensive equations for continuity, conservation of momentum, conservation of energy, and a conservation equation for each element in the alloy. The flow of the liquid in the mushy zone is dictated by the permeability, which is a function of fraction liquid and a characteristic length-scale of the dendritic structure (e.g. primary dendrite area spacing). As the fraction liquid approaches unity the permeability becomes infinity, and the transport conservation equations reduce to those of the all-liquid region. Thus, there is a natural transition and coupling of the transport phenomena in the mushy zone and the all-liquid zone. The model also accounts for the partitioning of each alloy element between solid and liquid. The density of the liquid (be it in the mushy zone or in the all-liquid zone) depends on its constitution and temperature; hence the liquid density varies spatially and temporally and is subject to gravity-driven convection. The fraction of liquid adjusts according to the constitution and freezing temperature of the liquid; hence both solidification and remelting during solidification are possible. An extensive list of properties for each alloy is required for running the computer simulations. These are presented in Tables 1 and 2 for the $\mathrm{Pb}-$ 2.2 wt.\% $\mathrm{Sb}$ alloy and the $\mathrm{Al}-2$ wt. $\% \mathrm{Cu}$ alloy, respectively.

\subsection{Simulations of convection in $\mathrm{Pb}-2.2 \mathrm{wt} \% \mathrm{Sb}$ alloy}

The alloy of $\mathrm{Pb}-2.2 \mathrm{wt} . \% \mathrm{Sb}$ is directionally solidified by simulation in a rectangular mold of $200 \mathrm{~mm}$ in height and various widths; gravity acts downward. Initially, the mold is filled with an all-liquid alloy of the nominal composition in a stable vertical temperature gradient such that the bottom temperature is slightly above that of the liquidus temperature. A constant thermal gradient $\left(8200 \mathrm{~K} \mathrm{~m}^{-1}\right.$ ) is imposed at the top, and a constant cooling rate $\left(0.0164 \mathrm{~K} \mathrm{~s}^{-1}\right)$ is applied at the bottom, which results in a solidification rate of $2 \mu \mathrm{m} \mathrm{s}^{-1}$. Lateral 
Table 1

Thermodynamic and transport properties of $\mathrm{Pb}-2.2 \mathrm{wt} . \% \mathrm{Sb}$ alloy

\begin{tabular}{lll}
\hline Property & Value & Reference \\
\hline $\begin{array}{lll}\text { Thermal expansion coefficient } \\
\left(\beta_{\mathrm{T}}\right)\end{array}$ & $-1.22 \times 10^{-4} \mathrm{~K}^{-1}$ & {$[17,18]$} \\
Density of liquid $\left(\rho_{1}\right)$ & $10552 \mathrm{~kg} \mathrm{~m}^{-3}$ & {$[17,18]$} \\
Density of solid $\left(\rho_{\mathrm{s}}\right)$ & $10944 \mathrm{~kg} \mathrm{~m}^{-3}$ & \\
Viscosity $(\mu)$ & $2.62 \times 10^{-3} \mathrm{~N} \mathrm{~s} \mathrm{~m}^{-2}$ & {$[19]$} \\
Diffusivity of solute in liquid $\left(D_{\mathrm{l}}\right)$ & $1.13 \times 10^{-9} \mathrm{~m}^{2} \mathrm{~s}^{-1}$ & {$[20]$} \\
Diffusivity of solute in solid $\left(D_{\mathrm{s}}\right)$ & $5.0 \times 10^{-13} \mathrm{~m}^{2} \mathrm{~s}^{-1}$ & $\mathrm{a}$ \\
Average thermal conductivity $(\kappa)$ & $15.2 \mathrm{~J} \mathrm{~K}^{-1} \mathrm{~m}^{-1} \mathrm{~s}^{-1}$ & {$[21,22]$} \\
Average specific heat of liquid $\left(c_{1}\right)$ & $152.390 \mathrm{~J} \mathrm{~kg}^{-1} \mathrm{~K}^{-1}$ & {$[23-26]$} \\
Average specific heat of solid $\left(c_{\mathrm{s}}\right)$ & $143.144 \mathrm{~J} \mathrm{~kg}^{-1} \mathrm{~K}^{-1}$ & \\
Latent heat of fusion $(L)$ & $2.9775 \times 10^{4} \mathrm{~J} \mathrm{~kg}$ & {$[23-26]$} \\
Reference temperature $\left(T_{\mathrm{R}}\right)$ & $587.6 \mathrm{~K}$ & {$[27]$} \\
Eutectic temperature $\left(T_{\mathrm{E}}\right)$ & $524.7 \mathrm{~K}$ & {$[27]$} \\
Solutal expansion coefficient & $-5.88 \times 10^{-3}$ & {$[17,18]$} \\
$\left(\beta_{\mathrm{C}}^{\text {Sb }}\right)$ & $(\mathrm{wt} . \%)^{-1}$ & \\
Slope of liquidus $\left(m^{\mathrm{Sb}}\right)$ & $-6.9911 \mathrm{~K}(\mathrm{wt} . \%)$ & {$[27]$} \\
Equilibrium partition ratio $\left(k_{\mathrm{Sb}}\right)$ & 0.3125 & {$[27]$} \\
\hline
\end{tabular}

${ }^{a}$ The code used for the simulations requires that a finite value of $D_{\mathrm{s}}$ be used, so $D_{\mathrm{s}}$ is made approximately four orders magnitude smaller than $D_{1}$.

walls are thermally insulated; liquid flows through the top boundary to compensate for the shrinkage. A noslip condition is used for velocity at the bottom and along the two vertical boundaries, and a stress-free condition is used on the top boundary. Solute diffusion flux is set to zero on the boundaries.

The experimental castings were solidified at $0.4 \mu \mathrm{m}$ $\mathrm{s}^{-1}$ under plane front conditions. The simulations duplicate the thermal gradient used in the experiment, but the simulated results are for $2 \mu \mathrm{m} \mathrm{s}^{-1}$. As explained above, the computer program is designed for simulating

Table 2

Thermodynamic and transport properties of $\mathrm{Al}-2 \mathrm{wt} . \% \mathrm{Cu}$ alloy

\begin{tabular}{lll}
\hline Property & Value & Reference \\
\hline Thermal expansion coefficient & $-1.0347 \times 10^{-4} \mathrm{~K}^{-1}$ & {$[28]$} \\
$\left(\beta_{\mathrm{T}}\right)$ & & \\
Density of liquid $\left(\rho_{\mathrm{l}}\right)$ & $2403.0 \mathrm{~kg} \mathrm{~m}^{-3}$ & {$[28]$} \\
Density of solid $\left(\rho_{\mathrm{s}}\right)$ & $2536.0 \mathrm{~kg} \mathrm{~m}^{-3}$ & \\
Viscosity $(\mu)$ & $1.379 \times 10^{-3} \mathrm{~N} \mathrm{~s} \mathrm{~m}^{-2}$ & {$[29]$} \\
Diffusivity of solute in liquid $\left(D_{1}\right)$ & $5.2 \times 10^{-9} \mathrm{~m}^{2} \mathrm{~s}^{-1}$ & {$[30,31]$} \\
Diffusivity of solute in solid $\left(D_{\mathrm{s}}\right)$ & $5.0 \times 10^{-13} \mathrm{~m}^{2} \mathrm{~s}^{-1}$ & $\mathrm{a}$ \\
Average thermal conductivity $(\kappa)$ & $121.0 \mathrm{~J} \mathrm{~K}^{-1} \mathrm{~m}^{-1} \mathrm{~s}^{-1}$ & {$[32]$} \\
Average specific heat of liquid $\left(c_{1}\right)$ & $1092 \mathrm{~J} \mathrm{~kg}^{-1} \mathrm{~K}^{-1}$ & {$[33]$} \\
Average specific heat of solid $\left(c_{\mathrm{s}}\right)$ & $1050 \mathrm{~J} \mathrm{~kg} \mathrm{~K}^{-1}$ & \\
Latent heat of fusion $(L)$ & $3.89 \times 10^{5} \mathrm{~J} \mathrm{~kg}^{-1}$ & {$[32]$} \\
Reference temperature $\left(T_{\mathrm{R}}\right)$ & $926.6 \mathrm{~K}$ & {$[34]$} \\
Eutectic temperature $\left(T_{\mathrm{E}}\right)$ & $821.2 \mathrm{~K}$ & {$[34]$} \\
Solutal expansion coefficient & $8.8416 \times 10^{-3}$ & {$[28]$} \\
$\left(\beta_{\mathrm{C}}^{\text {Cu }}\right)$ & $(\mathrm{wt} . \%)^{-1}$ & \\
Slope of liquidus $\left(m^{\mathrm{Cu}}\right)$ & $-3.433 \mathrm{~K}(\mathrm{wt} . \%)$ & {$[34]$} \\
Equilibrium partition ratio $(k)$ & 0.173 & {$[34]$} \\
\hline
\end{tabular}

a The code used for the simulations requires that a finite value of $D_{\mathrm{s}}$ be used, so $D_{\mathrm{s}}$ is made approximately four orders magnitude smaller than $D_{1}$. dendritic solidification with a mushy-zone of finite thickness. Solidification rates of less than $2 \mu \mathrm{m} \mathrm{s} \mathrm{s}^{-1}$ were attempted, but the calculated results were unrealistic and discounted. Similar computational anomalies were encountered and discussed by Huang et al. [35].

The solidification and convection in the $2-\mathrm{mm}$ wide domain of $\mathrm{Pb}-2.2$ wt.\% $\mathrm{Sb}$ was simulated, and the results of the bottom half at $2500 \mathrm{~s}$ are shown in Fig. 4(a) and (b). Fig. 4(a) shows thermosolutal convection as velocity vectors and contour lines indicating the mushy zone. Fig. 4(b) shows the total concentration of $\mathrm{Sb}$. During solidification, the Sb-enriched layer in the liquid above the dendrite tip makes the liquid unstable with respect to convection, and there are well-developed convection cells with a width of approximately half of the domain width. The maximum fluid velocity is 162 $\mu \mathrm{m} \mathrm{s}^{-1}$. Also notice that the convection results in the intrusions into the mushy zone at the intersection of the top of the mushy zone and the vertical boundaries.

To see the effect of width of domain on the convection, the solidification domains with widths of 1, 0.6 and $0.3 \mathrm{~mm}$ were solidified with the same thermal conditions as the domain with 2-mm width. As shown in Fig. 5(a) and (b), there are still well-developed convection cells for the cases with 1 and $0.6 \mathrm{~mm}$ of widths. It is observed that the maximum fluid velocity is decreased to 102 and $56 \mu \mathrm{m} \mathrm{s}^{-1}$, as the width is reduced to 1 and $0.6 \mathrm{~mm}$, respectively. Finally, no convection is observed at 0.3 $\mathrm{mm}$ of the domain width, and there are only small downward velocities due to shrinkage as shown in Fig. 5(c). These simulations certainly support the evidence of thermosolutal convection during solidification in capillaries as small as $1 \mathrm{~mm}$ (Fig. 3).

The thermosolutal convection in the $\mathrm{Pb}-2.2 \mathrm{wt} . \% \mathrm{Sb}$ alloy is driven by the Sb-enriched layer just above the top of the mushy zone [36]. Solidification at rates less than $2 \mu \mathrm{m} \mathrm{s}^{-1}$ would cause the enriched layer to have yet higher concentration of $\mathrm{Sb}$. That thermosolutal convection exists when the solidification rate is $2 \mu \mathrm{m}$ $\mathrm{s}^{-1}$ tells us that there is also thermosolutal convection at slower solidification rates, at least for widths of $0.6 \mathrm{~mm}$ or greater.

\subsection{Simulations of convection in $\mathrm{Al}-2 \mathrm{wt} \% \mathrm{Cu}$ alloy}

The alloy of $\mathrm{Al}-2 \mathrm{wt} . \% \mathrm{Cu}$ is directionally solidified by simulation in a rectangular mold of $200 \mathrm{~mm}$ in height and $6 \mathrm{~mm}$ in width; gravity acts downward. A constant thermal gradient $\left(9000 \mathrm{~K} \mathrm{~m}^{-1}\right)$ is imposed at the top, and a constant cooling rate $\left(0.036 \mathrm{~K} \mathrm{~s}^{-1}\right)$ is applied at the bottom that results in a solidification rate of $4 \mu \mathrm{m}$ $\mathrm{s}^{-1}$. The vertical surfaces were thermally insulated. Other boundary conditions are same as the case of $\mathrm{Pb}-\mathrm{Sb}$ alloy described above. Since the $\mathrm{Cu}$-enriched layer in the liquid above the dendrite tip is solutally 


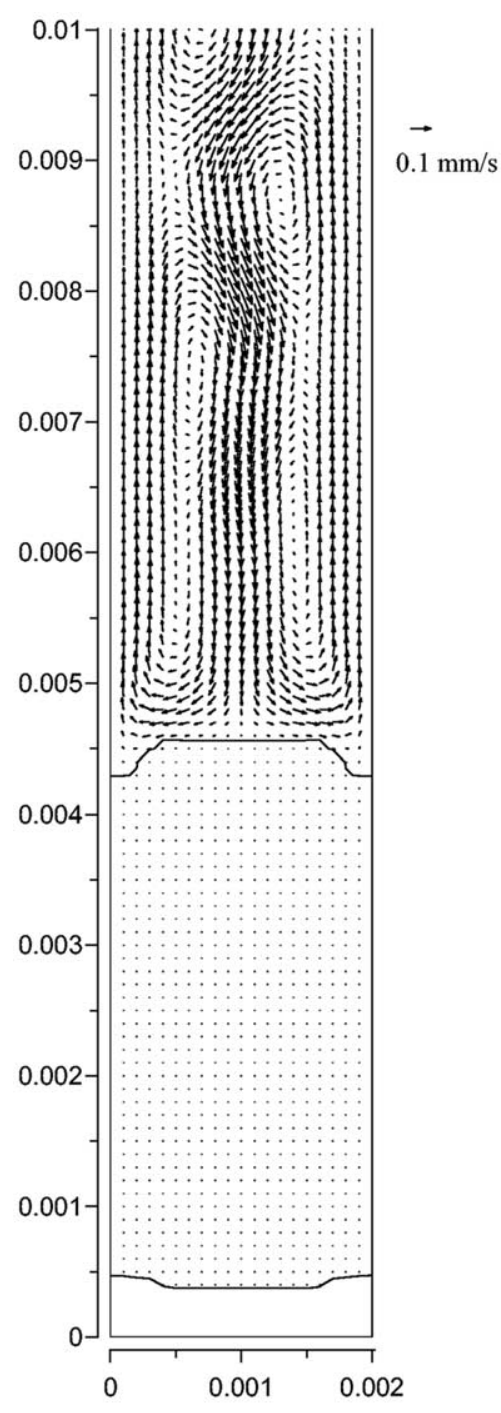

(a)

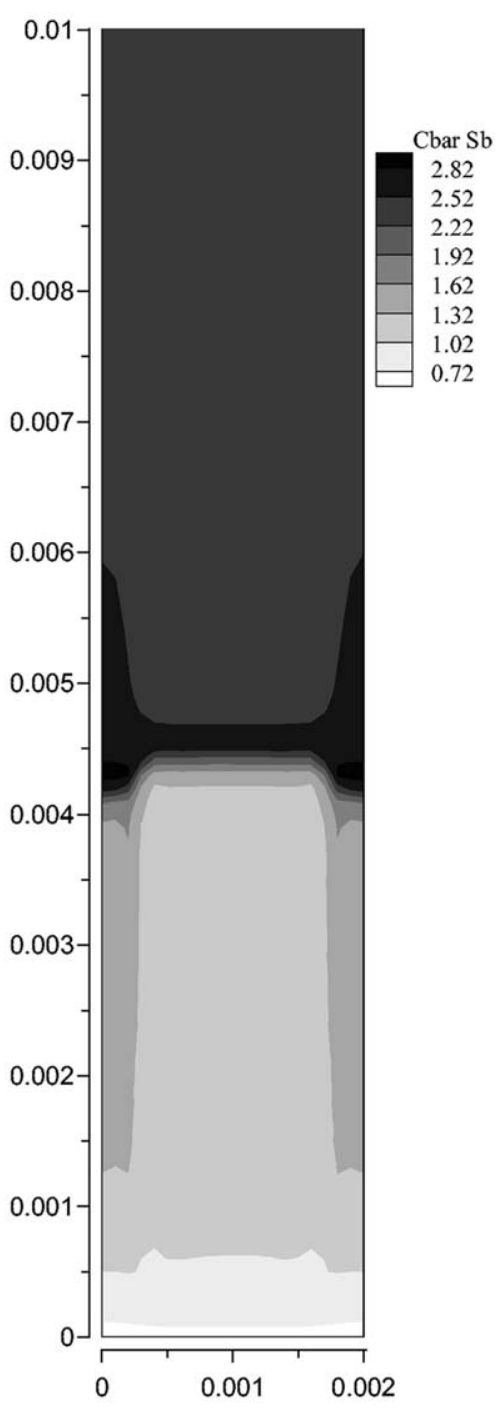

(b)

Fig. 4. Simulated results of $\mathrm{Pb}-2.2 \mathrm{wt} . \% \mathrm{Sb}$ at $2500 \mathrm{~s}$ : (a) thermosolutal convection and contour lines indicating mushy zone; (b) total concentration of $\mathrm{Sb}$, wt.\%. Dimensions of domain are in $\mathrm{m}$.

stable, no convection was observed in the domain with a width of $6 \mathrm{~mm}$.

The $\mathrm{Cu}$-concentration in the liquid at the dendrite tips is $C_{\mathrm{t}}=3.4 \mathrm{wt} . \%$. When the solidification rate becomes slower to reach planar solidification, the liquid concentration at the dendrite tips is as high as $C_{\mathrm{o}} / k$ (i.e. 11.6 wt. $\%$ with $C_{\mathrm{o}}=2$ wt. $\%$ and $k=0.173$ ). Hence, by artificially decreasing the equilibrium partition ratio of $\mathrm{Cu}(k)$ from 0.173 to 0.0173 and the slope of liquidus $\left(m_{\mathrm{L}}\right)$ from 3.433 to $0.344 \mathrm{~K}(\mathrm{wt} . \%)^{-1}$, the liquid concentration at the dendrite tips $\left(C_{\mathrm{t}}\right)$ can be increased to $11.6 \mathrm{wt} \%$ in the simulations. However, with thermally insulated vertical sides, there was still no thermosolutal convection simulated with the higher liquid concentrations at the dendrite tips. Hence, provided the vertical surfaces are thermally insulated, the $\mathrm{Al}-\mathrm{Cu}$ alloy exhibits no convection.

To observe the effect of lateral temperature gradient, a heat flux $\left(5.4 \times 10^{4} \mathrm{~J} \mathrm{~s}^{-1} \mathrm{~m}^{-2}\right)$ was imposed on the lateral wall instead of imposing the thermally insulated condition. The lateral heat flux was estimated from the experimental temperature profile and is approximately $5 \%$ of the heat flux through the bottom surface of the domain. As shown in Fig. 6(a) and (b), the convection arises from lateral temperature gradient of the domain width of $6 \mathrm{~mm}$, and the maximum fluid velocity is 133 $\mu \mathrm{m} \mathrm{s}^{-1}$. Similar calculations were done for smaller widths, and the convection persists for crucibles as small as $0.6 \mathrm{~mm}$ of diameter as a result of the lateral temperature gradient. 


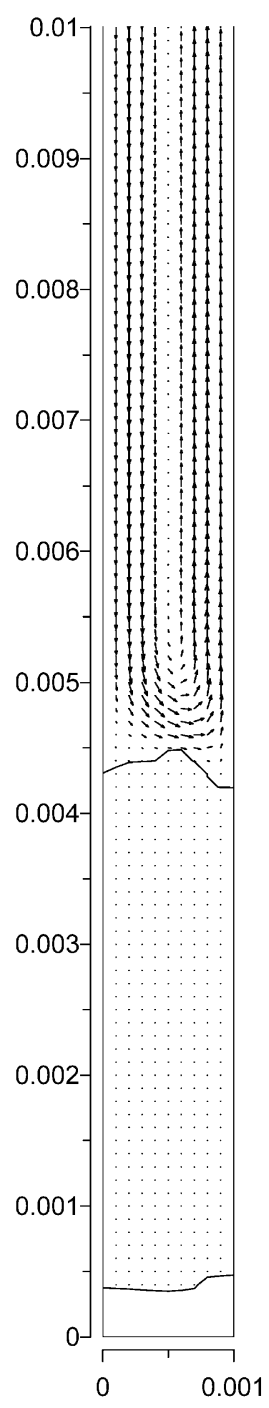

(a)

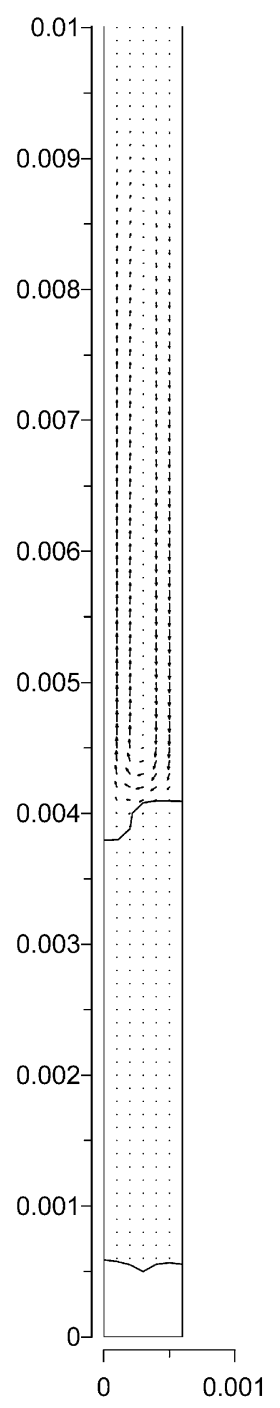

(b)

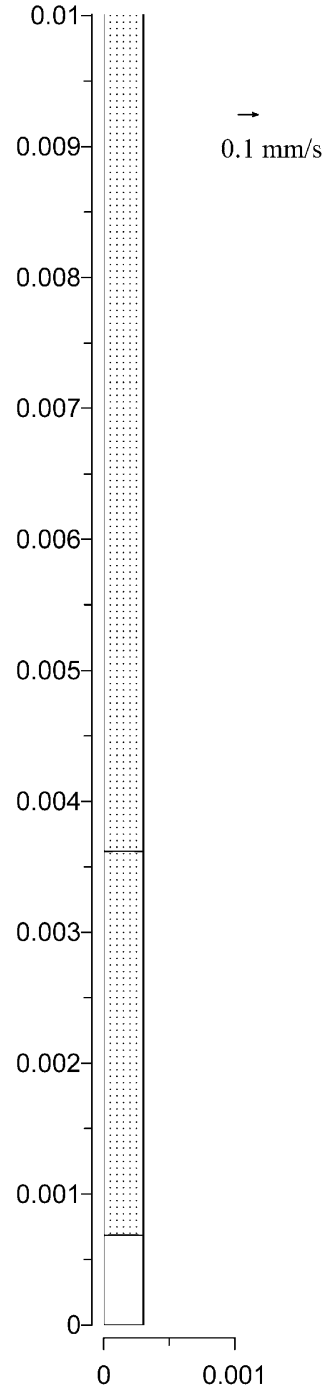

(c)

Fig. 5. Simulated results of $\mathrm{Pb}-2.2 \mathrm{wt} . \% \mathrm{Sb}$ at $2500 \mathrm{~s}$ : domain widths of (a) $1 \mathrm{~mm}$; (b) $0.6 \mathrm{~mm}$; and (c) $0.3 \mathrm{~mm}$. Contour lines indicate mushy zone. Dimensions of domain are in $\mathrm{m}$.

\section{Conclusions}

Following conclusions can be drawn from this study in which $\mathrm{Pb}-2.2$ wt.\% $\mathrm{Sb}$ and $\mathrm{Al}-2.2$ wt.\% $\mathrm{Cu}$ alloys were directionally solidified with planar liquid-solid interfaces.

(1) Convection during DS of $\mathrm{Pb}-2.2 \mathrm{wt} . \% \mathrm{Sb}$ alloy, with a planar liquid-solid interface, produces extensive longitudinal macrosegregation. Application of a $0.4 \mathrm{~T}$ transverse magnetic field has no effect on the extent of this convection or segregation. Reducing the ampoule diameter decreases the extent of convection. However, elimination of thermosolutal convection would require solidification in capillaries with diameters less than 600 $\mu \mathrm{m}$, which would introduce significant experimental difficulties.
(2) Convection driven by lateral thermal gradients occurred during the DS of the $\mathrm{Al}-2 \mathrm{wt} . \% \mathrm{Cu}$ alloy.

(3) Simulations performed for both alloys show that convection persists for crucibles as small as $0.6 \mathrm{~mm}$ in diameter. For the solutally stable alloy, $\mathrm{Al}-2 \mathrm{wt} . \% \mathrm{Cu}$, the simulations indicate that the convection arises from lateral temperature gradients.

\section{Acknowledgements}

This research was supported by NASA, administrated by the NASA-Marshall Space Flight Center, Huntsville, Alabama. Also, P.K. Sung and D.R. Poirier appreciate many discussions with Professor J.C. Heinrich of The 


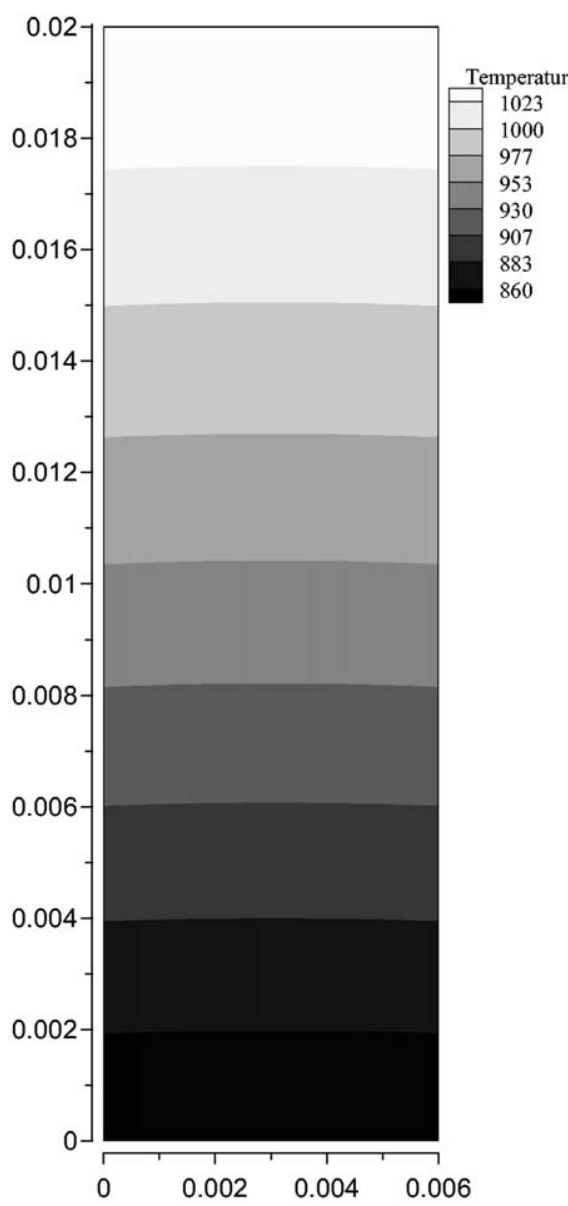

(a)

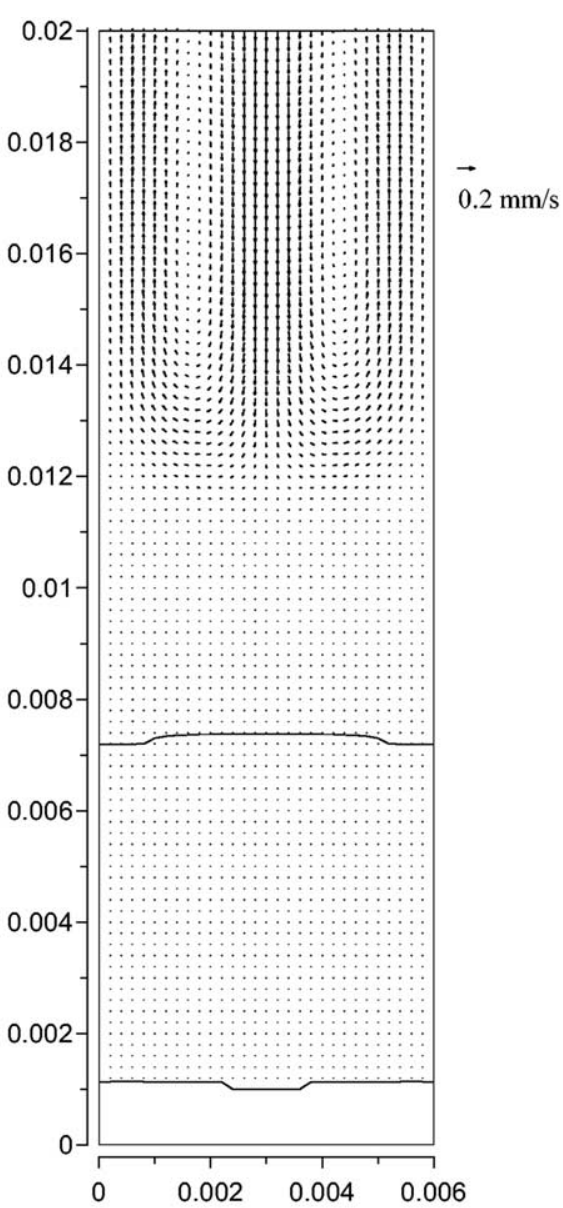

(b)

Fig. 6. Simulated results of $\mathrm{Al}-2 \mathrm{wt} . \% \mathrm{Cu}$ at $2500 \mathrm{~s}$ with lateral temperature gradient of the domain width of 6 mm: (a) temperature field; (b) thermosolutal convection and contour lines indicating mushy zone. Dimensions of domain are in $\mathrm{m}$.

University of Arizona on subjects of transport phenomena and finite element formulations.

\section{References}

[1] S.H. Davis, in: D.T.J. Hurle (Ed.), Handbook of Crystal Growth I Fundamentals, Part B: Transport and Stability, North Holand, Amsterdam, 1993, pp. 859-897.

[2] S.R. Coriell, B.T. Murray, A.A. Cherno, G.B. McFadden, Metall. Mater. Trans. A 27A (1996) 687-694.

[3] J.J. Favier, A. Rouzad, J. Crystal Growth 64 (1987) 367.

[4] S.N. Tewari, M.A. Chopra, J. Crystal Growth 118 (1992) $183-$ 192.

[5] H. Yu, K.N. Tandon, J.R. Cahoon, Metall. Mater. Trans. A 28A (1997) $1245-1250$.

[6] M.D. Dupouy, D. Camel, J.J. Favier, Acta Metall. Mater. 40 (1992) $1791-1799$.

[7] T. Okamoto, K. Kishitake, I. Bessho, J. Crystal Growth 29 (1975) $131-136$.

[8] R. Trivedi, H. Miyahara, P. Mazumder, E. Simsek, S.N. Tewari, J. Crystal Growth 222 (2000) 365-379.

[9] R. Trivedi, S. Liu, P. Mazumder, E. Simsek, Sci. Technol. Adv. Mater. 2 (2001) 309-320.
[10] S.N. Ojha, G. Ding, Y. Lu, J. Reye, S.N. Tewari, Metall. Mater. Trans. A 30A (1999) 2167-2171.

[11] S.N. Tewari, R. Shah, Metall. Mater. Trans. A 23A (1992) 33833392.

[12] S.N. Tewari, R. Shah, H. Song, Metall. Mater. Trans. A 25A (1994) 1535-1544.

[13] S.D. Felicelli, D.R. Poirier, J.C. Heinrich, J. Crystal Growth 177 (1997) $145-161$.

[14] S.D. Felicelli, J.C. Heinrich, D.R. Poirier, Int. J. Numer. Methods Fluids. 27 (1998) 207-227.

[15] S.D. Fellicelli, D.R. Poirier, P.K. Sung, Metall. Mater. Trans. B. 31B (2000) 1283-1292.

[16] M.C. Flemings, Solidification Processing, McGraw-Hill, New York, NY, 1974, p. 38.

[17] E.T. Turkdogan, Physical Chemistry of High Temperature Technology, Academic Press, New York, NY, 1980, p. 89.

[18] E.A. Brandes, G.B. Brook (Eds.), Smithells Metals Reference Book, seventh ed, Butterworth-Heinemann, Oxford, UK, 1992, pp. 14-18.

[19] M. Kucharski, Z. Metallkde. 77 (1986) 393.

[20] K. Niwa, M. Shimoji, S. Kado, Y. Watanabe, T. Yokokawa, Trans. AIME 209 (1957) 96-101.

[21] V.E. Zino'ev, Handbook of Thermophysical Properties of Metals at High Temperatures, Nova Science, New York, NY, 1996, p. 159. 
[22] Y.S. Touloukian, R.W. Powell, C.Y. Ho, P.G. Klemens, Thermophysical Properties of Matter, vol. 1, IFI/Plenum, New York, NY, 1970, p. 191.

[23] E.A. Brandes, G.B. Brook (Eds.), Smithells Metals Reference Book, seventh ed, Butterworth-Heinemann, Oxford, UK, 1992, pp. $8-42$.

[24] O. Kubaschewski, C.B. Alcock, P.J. Spencer, Materials Thermochemistry, sixth ed., Pergamon Press, Oxford, UK, 1993, pp. 301, 306,346 .

[25] R. Hultgren, R.L. Orr, P.D. Anderson, K.K. Kelly, Selected Values of Thermodynamic Properties of Metals and Alloys, Wiley, New York, NY, 1963, pp. 206-210, 247-252, 893-897.

[26] R.T. DeHoff, Thermodynamics in Materials Science, McGrawHill, New York, NY, 1993, p. 494.

[27] H. Okamoto (Ed.), Desk Handbook Phase Diagrams for Binary Alloys, ASM International, Materials Park, OH, 2000, p. 649.

[28] S. Ganesan, D.R. Poirier, Metall. Trans. A 18A (1987) 721-723.
[29] E. Rothwell, J. Inst. Met. 90 (1961) 389-394.

[30] J.B. Edwards, E.E. Hucke, J.J. Martin, Int. Met. Rev. 13 (1968) $1-28$.

[31] F.H. Wöhlbier (Ed.), Diffusion and Defect Data, vol. 25, Trans Tech Publications, Rockport, MA, 1981, pp. 111-112.

[32] S.R. Lampman, T.B. Zorc (Eds.), Metals Handbook, vol. 2, tenth ed, ASM International, Materials Park, OH, 1990, pp. 152-153.

[33] M.M. Mebed, H.A. Khalek, M.A. Abd Elnaiem, in: Proceedings of Condensed Papers Sixteenth Southeastern Seminar on Thermal Sciences (19-21 April 1982, Miami, FL), Clean Energy Research Institute, Coral Gables, FL, 1982, pp. 10-12.

[34] H. Okamoto (Ed.), Desk Handbook Phase Diagrams for Binary Alloys, ASM International, Materials Park, OH, 2000, p. 29.

[35] H.-W. Huang, J.C. Heinrich, D.R. Poirier, Numer. Heat Transfer, Part A 29 (1996) 639-644.

[36] C. Frueh, D.R. Poirier, R.G. Erdmann, S.D. Felicelli, Mater. Sci. Eng. A 345 (2003) 72-80. 